\title{
Cavitating leukodystrophy as a manifestation of cerebral involvement in MFN2 neuropathy
}

Ranjith Kumar Manokaran, MD, DM, Harsha Vardhan Mahalingam, MD, DNB, PDF, and Deepti Kewalramani, MD

Neurology ${ }^{\circledR}$ 2020;95:42-43. doi:10.1212/WNL.0000000000009746

A 16-year-old girl presented with progressive bilateral lower limb weakness for 3 years. Examination revealed tongue fasciculations, muscle wasting, and extensor plantar responses. Nerve conduction studies revealed motor-sensory axonal polyneuropathy. MRI brain showed multifocal cavitating white matter disease with diffusion restriction (figures 1 and 2). Exome sequencing revealed heterozygous missense variation c.775C $>\mathrm{T}$ (p.Arg259Cys) in exon 8 of the MFN2 gene, pathogenic for Charcot-Marie-Tooth disease 2A (CMT2A).

Dominant mutations of MFN2 (encoding mitochondrial protein mitofusin-2) cause a disorder of mitochondrial DNA maintenance ${ }^{1}$ resulting in axonal sensorimotor neuropathy.

\author{
Correspondence \\ Dr. Mahalingam \\ harsha.mahalingam@ \\ gmail.com
}

Figure 1 MRI brain: T2-weighted and T2-fluid-attenuated inversion recovery (FLAIR)weighted images

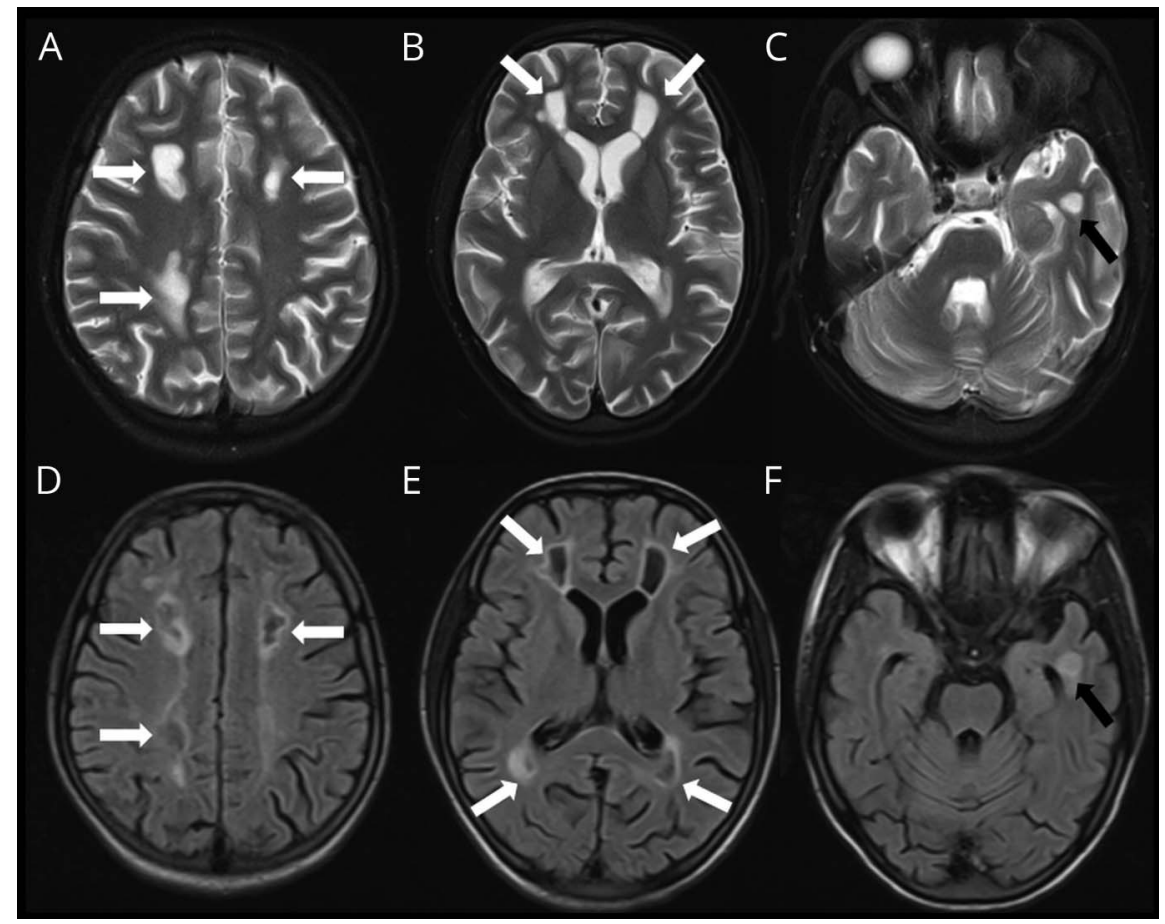

Axial T2-weighted images $(\mathrm{A}-\mathrm{C})$ show discrete hyperintense foci in periventricular and deep cerebral white matter. Axial T2-FLAIR images (D and E) show suppression of signal within the lesions suggesting cystic nature (white arrows). A nonsuppressed lesion (F) was seen in the left temporal lobe (black arrow).

From the Division of Paediatric Neurology (R.K.M.) and Department of Radiology (H.V.M.), Sri Ramachandra Institute of Higher Education and Research (SRIHER), Chennai; and Department of Pediatric Neurology (D.K.), BJ Wadia Children Hospital, Mumbai, India.

Go to Neurology.org/N for full disclosures. Funding information and disclosures deemed relevant by the authors, if any, are provided at the end of the article. 


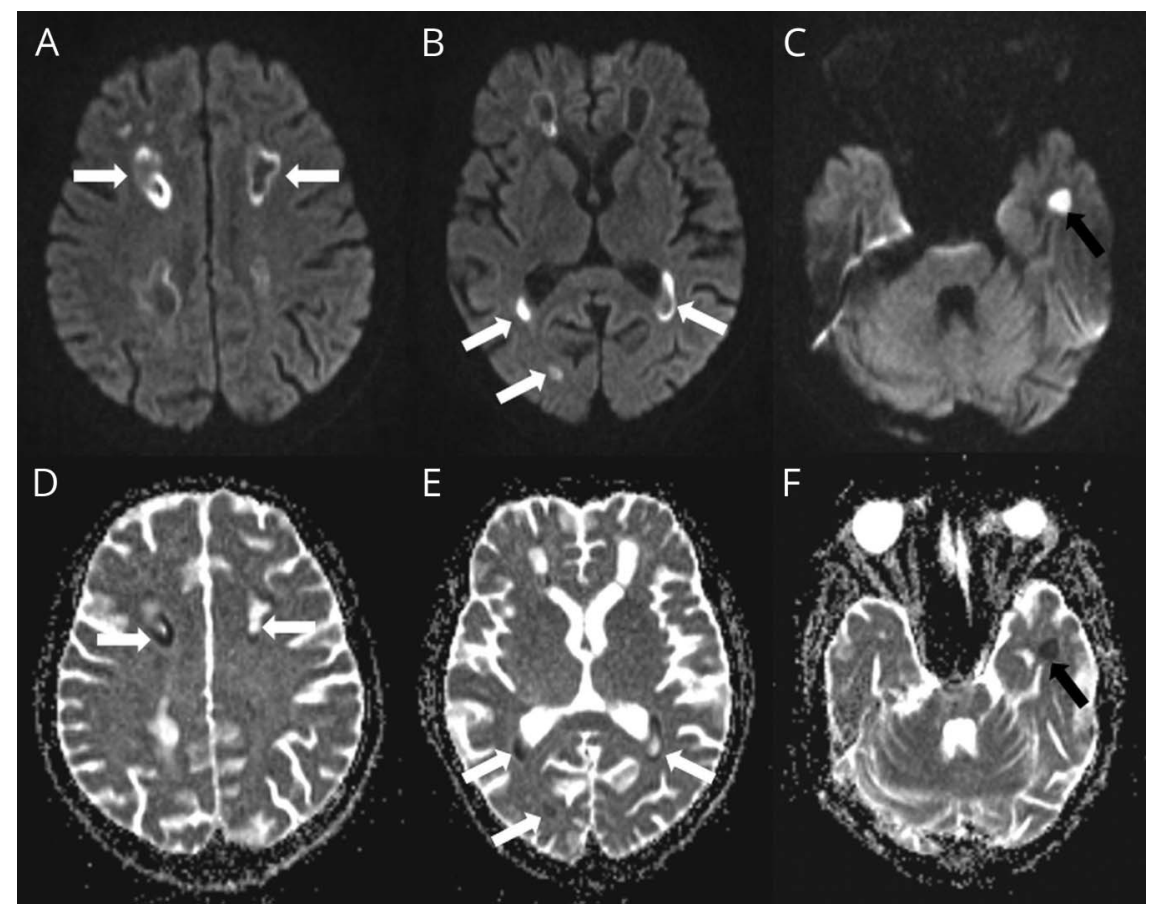

Axial diffusion-weighted images (A-C) and corresponding apparent diffusion coefficient maps (D-F) show diffusion restriction along the walls of some cystic lesions (white arrows) and solid diffusion restriction in the left temporal lobe lesion (black arrows). Spinal cord was normal (images not shown).
Nonspecific white matter alterations are reported in few patients with CMT2A. ${ }^{2}$ Multifocal cavitating leukodystrophy may be seen rarely.

\section{Study funding}

No targeted funding reported.

\section{Disclosure}

The authors report no relevant disclosures. Go to Neurology. org/ $\mathrm{N}$ for full disclosures.

Appendix Authors

\begin{tabular}{|c|c|c|}
\hline Name & Location & Contribution \\
\hline $\begin{array}{l}\text { Ranjith Kumar } \\
\text { Manokaran, MD, } \\
\text { DM }\end{array}$ & $\begin{array}{l}\text { Division of Paediatric } \\
\text { Neurology, Sri } \\
\text { Ramachandra Institute of } \\
\text { Higher Education and } \\
\text { Research (SRIHER), Chennai, } \\
\text { India }\end{array}$ & $\begin{array}{l}\text { Conceptualization, } \\
\text { data collection, } \\
\text { manuscript editing }\end{array}$ \\
\hline $\begin{array}{l}\text { Harsha Vardhan } \\
\text { Mahalingam, } \\
\text { MD, DNB, PDF }\end{array}$ & $\begin{array}{l}\text { Department of Radiology, } \\
\text { Sri Ramachandra Institute of } \\
\text { Higher Education and } \\
\text { Research (SRIHER), Chennai, } \\
\text { India }\end{array}$ & $\begin{array}{l}\text { Data collection, } \\
\text { manuscript drafting }\end{array}$ \\
\hline $\begin{array}{l}\text { Deepti } \\
\text { Kewalramani, } \\
\text { MD }\end{array}$ & $\begin{array}{l}\text { Department of Pediatric } \\
\text { Neurology, BJ Wadia } \\
\text { Children Hospital, Mumbai, } \\
\text { India }\end{array}$ & $\begin{array}{l}\text { Data collection, } \\
\text { manuscript drafting }\end{array}$ \\
\hline
\end{tabular}

\section{References}

1. Larrea D, Pera M, Gonnelli A, et al. MFN2 mutations in Charcot-Marie-Tooth disease alter mitochondria-associated ER membrane function but do not impair bioenergetics. Hum Mol Genet 2019;28:1782-1800.

2. Brockmann K, Dreha-Kulaczewski S, Dechent $P$, et al. Cerebral involvement in axonal Charcot-Marie-Tooth neuropathy caused by mitofusin2 mutations. J Neurol 2008; 255:1049-1058. 


\section{Neurology}

\section{Cavitating leukodystrophy as a manifestation of cerebral involvement in MFN2 neuropathy}

Ranjith Kumar Manokaran, Harsha Vardhan Mahalingam and Deepti Kewalramani Neurology 2020;95;42-43 Published Online before print June 10, 2020

DOI 10.1212/WNL.0000000000009746

\section{This information is current as of June 10, 2020}

\section{Updated Information \&} Services

References

Subspecialty Collections

Permissions \& Licensing

Reprints including high resolution figures, can be found at: http://n.neurology.org/content/95/1/42.full

This article cites 2 articles, 0 of which you can access for free at: http://n.neurology.org/content/95/1/42.full\#ref-list-1

This article, along with others on similar topics, appears in the following collection(s):

\section{All Genetics}

http://n.neurology.org/cgi/collection/all_genetics

Leukodystrophies

http://n.neurology.org/cgi/collection/leukodystrophies

Mitochondrial disorders

http://n.neurology.org/cgi/collection/mitochondrial_disorders

Mitochondrial disorders; see Genetics/Mitochondrial disorders http://n.neurology.org/cgi/collection/mitochondrial_disorders_see_gene tics-mitochondrial_disorders

MRI

http://n.neurology.org/cgi/collection/mri

Information about reproducing this article in parts (figures,tables) or in its entirety can be found online at:

http://www.neurology.org/about/about_the_journal\#permissions

Information about ordering reprints can be found online:

http://n.neurology.org/subscribers/advertise

Neurology ${ }^{\circledR}$ is the official journal of the American Academy of Neurology. Published continuously since 1951, it is now a weekly with 48 issues per year. Copyright () 2020 American Academy of Neurology. All rights reserved. Print ISSN: 0028-3878. Online ISSN: 1526-632X.

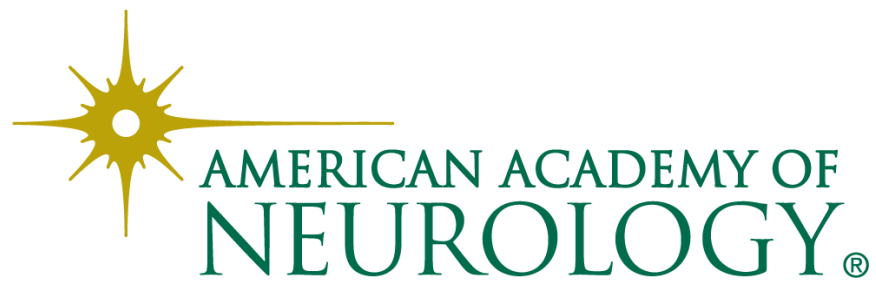

